Social Science History

The Official Journal of the Social Science History Association

VOLUME I5 NUMBER 2 SUMMER I99I

Published quarterly by Duke University Press 
Subscriptions Libraries and institutions \$50; individuals \$30; students \$12. (Add \$6.0o for postage outside the United States.) Individual and student rates include membership in the Social Science History Association; all such subscribers will receive information from the SSHA, as well as copies of the journal.

Recent back issues \$13; back volume \$50: Make payment to Duke University Press, Journals Department, 6697 College Station, Durham, NC 27708, USA. Volumes I-IO are available from Schmidt Periodicals $\mathrm{GmbH}$, Dettendorf, D-820I Bad Feilnbach 2, West Germany: Please write directly to Schmidt for information and prices.

Membership inquiries should be addressed to Howard W. Allen, Dept. of History, Southern Illinois University at Carbondale, Carbondale, IL 6290I .

Claims for missing issues should be made within two months following the regular month of publication; the publishers will supply missing numbers without charge only when losses have been sustained in transit and when reserve stock will permit. For library exchange proposals, address Duke University Library, Gift and Exchange Dept., Durham, NC 27706, USA.

Photocopying Photocopies for course or research use that are supplied to the end-user at no cost may be made without need for explicit permission or fee. Photocopies that are to be provided to their end-users for some photocopying fee may not be made without payment of permissions fees to Duke University. Press, at 25 cents per copy for each article copied. Registered users may pay for photocopying via the Copyright Clearance Center, using the code and price at the bottom of each article-opening page.

Permissions Requests for permission to republish copyrighted material from this journal should be addressed to Permissions Editor, Duke University Press, 6697 College Station, Durham, NC 27708.

Advertising Current rates and specifications may be obtained by writing to the Marketing Manager at Duke University Press.

Social Science History is listed in Applied Social Science Index and Abstracts, Current Contents, Social Sciences Citation Index, and the United States Political Science Documents.

Copyright (C) 1991 by the Social Science History Association US ISSN 0I 45-5532. 


\section{Social Science History}

The Official Journal of the Social Science History Association

VOLUME I 5 , NUMBER 2

SUMMER I99I

The Voices and Audiences of Social History Records

BARBARA A. HANAWALT I59

Structural versus Functional Determinants of New York's Fiscal Policies towards Metropolitan Transportation, I904-1990 JAMES K. COHEN 177

Introduction: History and the Other Social Sciences, Part I ERIC MONKKONEN 199

History and Sociology: The Lost Synthesis ANDREW ABBOTT 201

History and Economics HUGH ROCKOFF 239

History, Geography, and Historical Geography RICHARD DENNIS 265 
SOCIAL SCIENCE HISTORY is the journal of the Social Science History Association and exists to publish material directed to improving the quality of historical explanation in teaching and research of relevant theories and methods from the social science disciplines. It is aimed at social scientists interested in longitudinal analysis and historians seeking a more rigorous and consciously theoretical orientation. The editors encourage and provide a forum for research that attempts generalizations of some breadth verified by systematic examination of the relevant evidence and supported by quantitative analysis when appropriate. Research efforts involving comparisons across time between individuals and groups within a single population and between different and properly comparable populations across space and over time will be particularly welcome. The editors welcome contributions to the development of theory and techniques which, although firmly centered in particular social science disciplines, can provide a genuine interdisciplinary focus in approaching the historical dimension. Social Science History will also inform its readers about new developments in social science data archives, research funding agencies, training programs and summer institutes, and significant new publications in history and the social science disciplines.

MANUSCRIPTS should be submitted in triplicate to Eric Monkkonen, Department of History, University of California, Los Angeles, CA 90024. They must be typed with all written material double-spaced (including quotations, notes, and the list of references) using only one side of the paper. The typewritten lines should not exceed $5^{1 / 2}$ inches in length. Brief parenthetical citations are included in the text, all complete references are listed alphabetically at the end of the article, and notes are used only for discursive comments and appear immediately before the list of references. Contributors may request a "Style Guide for Authors" from the editor or refer to Social Science History 14:2, pages 28187 for detailed information on this journal's style. The Social Science History Association does not accept responsibility for statements of fact or opinion made by the contributors.

Social Science History (ISSN: OI45-5532) is published quarterly, at $\$ 50$ for institutions and libraries and \$30 for individuals, for the Social Science History Association by Duke University Press, Box 6697 College Station, Durham, NC 27708. Second-class postage paid at Durham, NC. POSTMASTER: Send address changes to Duke University Press, Box 6697 College Station, Durham, NC 27708 . 